\title{
MỌTT SỐ YẾU TỐ NGUY CƠ LIÊN QUAN TĂNG ÁP ĐộNG MẠCH PHỔI TRÊN BỆNH NHÂN XƠ CỨNG BÌ, LUPUS BAN ĐỎ HẸ THỐNG
}

\author{
Trần Thị Linh Tú ${ }^{1, 凹}$, Trương Thanh Hương ${ }^{2}$ \\ ${ }^{1}$ Bệnh viện Tim Hà Nội, \\ ²Viện Tim mạch Việt Nam
}

Tăng áp động mạch phổi ở nhóm bệnh nhân tự miễn là yếu tố báo hiệu tiên lượng xấu của bệnh và gây ảnh hưởng nặng nề hơn so với nhóm bệnh nhân tăng áp động mạch phổi khác. Siêu âm tim qua thành ngực có giá trị trong sàng lọc và đánh giá mức độ tổn thương tim mạch trong xơ cứng bì, lupus ban đỏ hệ thống, cùng với những chỉ số khác như test đi bộ 6 phút và NT proBNP, NYHA. Nghiên cứu của chúng tôi tiến hành nhằm đánh giá một số yếu tố nguy cơ liên quan tăng áp động mạch phổi trên bệnh nhân xơ cứng bì, lupus ban đỏ hệ thống. Nghiên cứu tiến hành trên 199 bệnh nhân (137 bệnh nhân lupus ban đỏ hệ thống, 62 bệnh nhân xơ cứng bi) tại trung tâm Dị ứng - Miễn dịch lâm sàng bệnh viện Bạch Mai, Viện Da liễu trung ương từ tháng 8 năm 2016 đến tháng 8 năm 2020 được siêu âm tim xác định 61 ca tăng áp động mạch phổi (áp lực động mạch phổi tâm thu > $36 \mathrm{mmHg}$ ), 138 ca áp lực động mạch phổi bình thường. Kết quả cho thấy, nồng độ NT - proBNP tăng và mức độ khó thở nặng hơn ở nhóm tăng áp động mạch phổi, trong khi đó khoảng cách đi bộ ở nhóm tăng áp động mạch phổi lại ngắn hơn. Mức độ khó thở NYHA và nồng độ NT - proBNP là yếu tố nguy cơ độc lập liên quan đến tăng áp động mạch phổi ở bệnh nhân lupus ban đỏ hệ thống và xơ cứng bì.

Từ khóa: Tăng áp động mạch phổi, xơ cứng bì, lupus ban đỏ hệ thống, NT - proBNP, NYHA.

\section{I. ĐẠT VẤN ĐỀ}

Tăng áp động mạch phổi ở nhóm bệnh nhân tự miễn là yếu tố báo hiệu tiên lượng xấu của bệnh và gây ảnh hưởng nặng nề hơn so với nhóm bệnh nhân tăng áp động mạch phổi khác. Bệnh nhân xơ cứng bì có tăng áp động mạch phổi không được điều trị, thời gian sống sau 1 năm $50 \%$, còn ở bệnh nhân không có tăng áp lực động mạch phổi là trên $90 \%$. $^{1}$ Bệnh nhân lupus ban đỏ hệ thống (LPBĐHT), tî lệ sống sau 5 năm ở nhóm không tăng áp động mạch phổi là $95 \%,{ }^{2}$ trong khi ở nhóm có tăng áp động mạch phổi chỉ có $70,1 \%{ }^{3}$ Triệu chứng của tăng áp động mạch phổi thường kín đáo và không

Tác giả liên hệ: Trần Thị Linh Tú,

Bệnh viện Tim Hà Nội

Email: hieutub@yahoo.fr

Ngày nhận: 13/09/2020

Ngày được chấp nhận: 11/01/2021 đặc hiệu nên việc chẩn đoán thường muộn. Điều này đòi hỏi cần có những công cụ để có thể sàng lọc phát hiện sớm tăng áp động mạch phổi ở nhóm bệnh tự miễn, giúp can thiệp sớm và cải thiện tiên lượng cho bệnh nhân. Một số chỉ số lâm sàng, cận lâm sàng có liên quan đến thay đổi áp lực động mạch phổi và chức năng thất phải như khoảng cách đi bộ 6 phút, nồng độ NT proBNP, và mức độ khó thở NYHA đã được đề cập đến trong hướng dẫn của ESC 2015 giúp phân tầng nguy cơ tăng áp động mạch phổi. Test đi bộ 6 phút thể hiện khả năng dung nạp của hô hấp với gắng sức, khoảng cách đi bộ 6 phút có liên quan đến tiên lượng sống của bệnh nhân tăng áp động mạch phổi, ${ }^{4}$ trong khi đó NT - proBNP là dấu ấn sinh học phản ánh đáp ứng của cơ tim với áp lực và quá tải thể tích, ${ }^{5}$ biến đổi song song với thay đổi trong cấu trúc và chức năng thất phải. ${ }^{6}$ NYHA tập trung 
vào phản ánh khả năng gắng sức, cung cấp thông tin về sự có mặt của suy tim và mức độ suy tim, đặc biệt trong phân biệt thay đổi chức năng thất phải có và không có triệu chứng. ${ }^{7}$ Để kiểm chứng lại những giả thuyết trên, chúng tôi tiến hành nghiên cứu với mục tiêu: "Đánh giá một số yếu tố nguy cơ liên quan tăng áp động mạch phổi trên bệnh nhân xơ cứng bì, lupus ban đỏ hệ thống".

\section{II. ĐÓI TƯỢNG VÀ PHƯƠNG PHÁP}

\section{1. Đối tượng}

199 bệnh nhân (137 bệnh nhân LPBĐHT, 62 bệnh nhân xơ cứng bì) tại trung tâm Dị ứng Miễn dịch lâm sàng bệnh viện Bạch Mai, Viện Da liễu trung ương từ tháng 8 năm 2016 đến tháng 8 năm 2020 được siêu âm tim xác định 61 ca tăng áp động mạch phổi (áp lực động mạch phổi tâm thu > $36 \mathrm{mmHg}$ ), 138 ca áp lực động mạch phổi bình thường.

\section{Tiêu chuẩn lựa chọn:}

- Bệnh nhân được chẩn đoán lupus ban đỏ hệ thống theo tiêu chuẩn SLICC 2012, xơ cứng bì theo tiêu chuẩn ACR/EULAR NĂM 2013

- Bệnh nhân có độ tuổi trong khoảng > 18 tuổi và < 85 tuổi

- Bệnh nhân đồng ý tham gia nghiên cứu

- Chẩn đoán tăng áp động mạch phổi dựa vào siêu âm tim theo ESC/ERC 2009, chọn ngưỡng áp lực động mạch phổi tâm thu > 36 mmHg làm tiêu chuẩn chọn bệnh nhân vào nhóm tăng áp động mạch phổi.

\section{Tiêu chuẩn loại trù̀:}

- Có triệu chứng lâm sàng, cận lâm sàng của bệnh lý động mạch vành.

- Rối loạn dẫn truyền, rối loạn nhịp tim có thể gây khó khăn hay có thể làm sai lệch kết quả nghiên cứu bằng Doppler tim.

- Tiền sử hay hiện tại mắc C.O.P.D hoặc đang phải sử dụng thường xuyên các thuốc giãn phế quản;

- C Cửa sổ siêu âm Doppler tim mờ, không làm được siêu âm tim.

- Phụ nữ có thai, cho con bú.

- Bệnh nhân không đồng ý tham gia nghiên cứu.

- Bệnh nhân tăng áp động mạch phổi do nguyên nhân khác

\section{Phương pháp}

Thiết kế nghiên cứu, cỡ mẫu: Nghiên cứu mô tả cắt ngang, cỡ mẫu thuận tiện.

\section{Tiến hành nghiên cứu:}

Tất cả bệnh nhân thỏa mãn tiêu chuẩn được hỏi tiền sử, bệnh sử, khám lâm sàng toàn diện, làm xét nghiệm công thức máu, sinh hóa máu, xét nghiệm miễn dịch, chụp Xquang phổi, điện tâm đồ và siêu âm Doppler tim đánh giá. Tất cả các dữ liệu sẽ được ghi vào mẫu bệnh án nghiên cứu. Xử lí số liệu và đưa ra kết luận.

\section{Phương pháp siêu âm tim:}

Siêu âm Doppler tim qua thành ngực được thực hiện tại phòng siêu âm tim viện Tim mạch Việt Nam. Sử dụng máy siêu âm nhãn hiệu Vivid E09. Siêu âm với các mặt cắt siêu âm: mặt cắt trục ngắn cạnh ức, mặt cắt trục dài cạnh ức, mặt cắt bốn buồng tại mỏm tập trung vào thất phải, mặt cắt hai buồng tập trung vào thất phải, mode Doppler xung, Doppler liên tục qua van ba lá, qua van động mạch phổi, mode doppler mô ở vùng bên vòng van ba lá, mode TM ở vùng bên vòng van ba lá, mode Doppler xung ở buồng tống thất phải.

Các phép đo siêu âm: có thể tiến hành tất cả các siêu âm tim ( $T M$; 2D, các siêu âm Doppler: xung, liên tục, màu, mô...) được cài đặt chương trình phần mềm cho phép tính toán các thông số đánh giá chức năng một cách tự động. Lấy trung bình của ba phép đo liên tiếp.

Áp lực động mạch phổi tâm thu được ước tính qua vận tốc của dòng hở van ba lá dùng phương trình Bernoulli tối giản và kết hợp giá 
trị này với ước tính áp lực nhĩ phải : 4 V². + RAP trong đó $V$ là vận tốc tối đa $(\mathrm{m} / \mathrm{s})$ của dòng hở van ba lá và RAP là áp lực nhĩ phải được ước tính qua đường kính tĩnh mạch chủ dưới và sự thay đổi theo hô hấp của tĩnh mạch này, khi không có chênh áp qua van phổi và trong buồng thất phải.

\section{Xử lí số liệu}

Nhập số liệu bằng phần mềm SPSS 20.0. Sử dụng các thuật toán min, max, trung bình và độ lệch chuẩn, tính tỉ lệ. Sử dụng các test thống kê phù hợp: Test ANOVA, test Khi bình phương, Fisher exact test, Independent samples $T$ test.
Lấy mức ý nghĩa thống kê khi $p<0,05$. Thuật toán spearmen.

\section{4. Đạo đức nghiên cứu}

Tất cả các hoạt động tiến hành trong nghiên cứu này đều tuân thủ qui định và nguyên tắc chuẩn mực về đạo đức nghiên cứu y sinh học của Việt Nam và quốc tế. Các hoạt động nghiên cứu không gây nguy hiểm và các nguy cơ cho đối tượng nghiên cứu. Tất cả các đối tượng nghiên cứu tự nguyện tham gia vào nghiên cứu sau khi được tư vấn đầy đủ. Các số liệu y học mang tính cá nhân trong nghiên cứu được đảm bảo nguyên tắc bí mật.

\section{KÉT QUẢ}

\section{1. Đặc điểm chung nhóm nghiên cứu}

Bảng 1. Đặc điểm chung của nhóm nghiên cứu

\begin{tabular}{|c|c|c|c|c|}
\hline & Nhóm & $\begin{array}{l}\text { Tuổi } \\
\text { (năm) }\end{array}$ & Giới nũ (\%) & $\begin{array}{c}\text { Thời gian mắc } \\
\text { (tháng) }\end{array}$ \\
\hline \multirow{3}{*}{$\begin{array}{l}\text { Chung } \\
(n=199)\end{array}$} & Có PAH (n = 61) & $44 \pm 1,06$ & 83,6 & $50,49 \pm 6,83$ \\
\hline & Không PAH $(n=138)$ & $38,25 \pm 1,94$ & 88,4 & $38,45 \pm 3,81$ \\
\hline & $\mathrm{p}$ & 0,01 & 0,35 & 0,10 \\
\hline \multirow{3}{*}{$\begin{array}{l}\text { LPBĐHT } \\
(n=137)\end{array}$} & Có PAH (n = 33) & $36,55 \pm 2,48$ & 84,8 & $34,73 \pm 7,20$ \\
\hline & Không PAH $(n=104)$ & $33,72 \pm 2,48$ & 84,8 & $34,73 \pm 7,20$ \\
\hline & $\mathrm{p}$ & 0,29 & 0,69 & 0,85 \\
\hline \multirow{3}{*}{$\begin{array}{l}\text { xơ cứng bì } \\
(\mathrm{n}=62)\end{array}$} & Có PAH (n = 28) & $52,79 \pm 2,11$ & 82,1 & $69,07 \pm 11,40$ \\
\hline & Không PAH $(n=34)$ & $52,09 \pm 1,64$ & 91,2 & $44,97 \pm 8,25$ \\
\hline & $p$ & 0,79 & 0,29 & 0,08 \\
\hline
\end{tabular}

Đặc điểm tuổi, giới và thời gian mắc của nhóm có tăng áp động mạch phổi và không tăng áp động mạch phổi là như nhau trên cả hai đối tượng LPBĐHT và xơ cứng bì. Tỉ lệ tăng áp động mạch phổi trên đối tượng lupus ban đỏ hệ thống là 24,1\%, bệnh nhân xơ cứng bì là 45,2\%.

\section{2. Đặc điểm lâm sàng, cận lâm sàng}

\section{Bảng 2. Chức năng thất phải trên siêu âm tim}

\begin{tabular}{lcccccc}
\hline \multirow{2}{*}{ Chỉ số } & \multicolumn{3}{c}{ LPBĐHT $(\mathbf{n}=\mathbf{1 3 7})$} & \multicolumn{3}{c}{ Xơ cứng bì $(\mathbf{n}=\mathbf{6 2})$} \\
\cline { 2 - 7 } & PAH & Không PAH & p & PAH & Không PAH & p \\
\hline TAPSE & $20,59 \pm 0,93$ & $21,28 \pm 0,93$ & 0,49 & $18,39 \pm 0,69$ & $21,02 \pm 0,64$ & 0,007 \\
\hline sPAP & $54,27 \pm 2,77$ & $26,86 \pm 0,46$ & 0,00 & $45,47 \pm 2,19$ & $27,06 \pm 0,82$ & 0,00 \\
\hline ST - GS & $21,33 \pm 1,11$ & $26,56 \pm 2,66$ & 0,07 & $18,60 \pm 0,89$ & $28,20 \pm 7,55$ & 0,26 \\
\hline \hline
\end{tabular}




\begin{tabular}{lcccccc}
\hline \multirow{2}{*}{ Chỉ số } & \multicolumn{3}{c}{ LPBĐHT $(\mathbf{n = 1 3 7 )}$} & \multicolumn{3}{c}{ Xơ cúng bì $(\mathbf{n}=\mathbf{6 2})$} \\
\cline { 2 - 7 } & PAH & Không PAH & $\mathbf{p}$ & PAH & Không PAH & $\mathbf{p}$ \\
\hline ALNP & $4,45 \pm 0,36$ & $3,89 \pm 0,14$ & 0,07 & $4,36 \pm 0,35$ & $3,64 \pm 0,16$ & 0,07 \\
\hline FAC & $38,40 \pm 2,62$ & $38,99 \pm 1,47$ & 0,84 & $30,56 \pm 2,37$ & $38,84 \pm 2,14$ & 0,01 \\
\hline PVR & $2,26 \pm 0,12$ & $2,57 \pm 0,84$ & 0,83 & $2,71 \pm 0,19$ & $1,57 \pm 0,07$ & 0,00 \\
\hline
\end{tabular}

*LPBĐHT: lupus ban đỏ hệ thống

Trên đối tượng lupus ban đỏ hệ thống các chỉ số về chức năng thất phải là như nhau giữa hai nhóm có tăng áp động mạch phổi và không có tăng áp động mạch phổi. Trên đối tượng xơ cứng bì, có sự khác biệt rõ rệt chỉ số thất phải và kháng lực mạch phổi giữa nhóm có và không có tăng áp động mạch phổi.

Bảng 3. Đặc điểm lâm sàng, cận lâm sàng

\begin{tabular}{|c|c|c|c|c|}
\hline & Nhóm & Test đi bộ 6 phút & NYHA & NT - proBNP \\
\hline \multirow{3}{*}{$\begin{array}{l}\text { LPBĐHT } \\
\qquad(\mathrm{n}=137)\end{array}$} & Không PAH & $467,40 \pm 9.24$ & $1,28 \pm 0,05$ & $128,24 \pm 37,83$ \\
\hline & Có PAH & $372,42 \pm 20,81$ & $1,88 \pm 0,14$ & $384,91 \pm 81,45$ \\
\hline & $p$ & 0,00 & 0,00 & 0,006 \\
\hline \multirow{3}{*}{$\begin{array}{l}\text { xơ cứng bì } \\
(\mathrm{n}=62)\end{array}$} & Không PAH & $375,00 \pm 12,33$ & $1,62 \pm 0,09$ & $53,85 \pm 35,37$ \\
\hline & Có PAH & $327,50 \pm 15,88$ & $2,00 \pm 0,12$ & $288,82 \pm 86,19$ \\
\hline & $p$ & 0,02 & 0,01 & 0,02 \\
\hline
\end{tabular}

Nồng độ NT - proBNP ở nhóm tăng áp động mạch trên cả hai đối tượng lupus ban đỏ hệ thống và xơ cứng bì cao hơn nhóm không tăng áp động mạch phổi. Trong khi khoảng cách đi bộ 6 phút ở nhóm tăng áp động mạch phổi ngắn hơn nhóm không tăng áp động mạch phổi trên cả hai đối tượng lupus ban đỏ hệ thống và xơ cứng bì. Mức độ khó thở NYHA của bệnh nhân tăng áp động mạch phổi cao hơn hẳn so với nhóm không tăng áp động mạch phổi ở cả hai nhóm đối tượng nghiên cứu.

3. Mối liên quan giữa chức năng thất phải và chỉ số lâm sàng, cận lâm sàng

Bảng 4. Mối liên quan giữa chức năng thất phải và chỉ số lâm sàng, cận lâm sàng nhóm bệnh nhân lupus ban đỏ hệ thống ( $\mathrm{n}=137)$

\begin{tabular}{lcccccc}
\hline \multirow{2}{*}{ Chỉ số } & \multicolumn{2}{c}{ Nồng độ NT - proBNP } & Khoảng cách test đi bộ $\mathbf{6}$ phút & \multicolumn{2}{c}{ NYHA } \\
\cline { 2 - 7 } & $\mathbf{r}$ & $\mathbf{p}$ & $\mathbf{r}$ & $\mathbf{p}$ & $\mathbf{r}$ & $\mathbf{p}$ \\
\hline TAPSE & 0,04 & 0,57 & 0,15 & 0,08 & $-0,25$ & 0,04 \\
\hline FAC & 0,09 & 0,28 & 0,03 & 0,69 & $-0,18$ & 0,03 \\
\hline GS & $-0,57$ & 0,56 & 0,13 & 0,12 & $-0,14$ & 0,11 \\
\hline PVR & $-0,03$ & 0,74 & $-0,05$ & 0,59 & 0,003 & 0,98 \\
\hline ALNP & 0,05 & 0,53 & 0,04 & 0,65 & -0.08 & 0,37 \\
\hline SPAP & 0,28 & 0,001 & $-0,39$ & 0,00 & 0,52 & 0,00 \\
\hline
\end{tabular}


Bảng 5. Mối liên quan giữa chức năng thất phải và chỉ số lâm sàng, cận lâm sàng trên nhóm bệnh nhân xơ cứng bì $(n=62)$

\begin{tabular}{lcccccc}
\hline \multirow{2}{*}{ Chỉ số } & \multicolumn{2}{c}{ Nồng độ NT - proBNP } & Khoảng cách test đi bộ $\mathbf{6}$ phút & \multicolumn{2}{c}{ NYHA } \\
\cline { 2 - 7 } & $\mathbf{r}$ & $\mathbf{p}$ & $\mathbf{r}$ & $\mathbf{p}$ & $\mathbf{r}$ & $\mathbf{p}$ \\
\hline TAPSE & $-0,04$ & 0,83 & 0,02 & 0,91 & $-0,16$ & 0,21 \\
\hline FAC & $-0,07$ & 0,68 & $-0,55$ & 0,68 & 0,09 & 0,47 \\
\hline GS & $-0,05$ & 0,76 & $-0,03$ & 0,79 & $-0,173$ & 0,18 \\
\hline PVR & 0,32 & 0,07 & $-0,02$ & 0,23 & 0,33 & 0,009 \\
\hline ALNP & $-0,08$ & 0,49 & 0,01 & 0,96 & 0,11 & 0,93 \\
\hline sPAP & 0,48 & 0,004 & $-0,207$ & 0,106 & 0,31 & 0,01 \\
\hline
\end{tabular}

Trong nhóm bệnh nhân lupus ban đỏ hệ thống áp lực động mạch phổi tâm thu có mối tương quan thuận với nồng độ NT - proBNP $(r=0,28, p=0,001)$ và mối tương quan nghịch với khoảng cách đi bộ 6 phút $(r=-0,39, p=0,00)$. NYHA có mối tương quan với cả chỉ số áp lực động mạch phổi và chỉ số chức năng thất phải TAPSE và $F A C$

Trong nhóm bệnh nhân xơ cứng bì có mối tương quan thuận giữa nồng độ NT - proBNP huyết thanh và áp lực động mạch phổi tâm thu $(r=0,48, p=0,004)$. NYHA có mối tương quan với kháng lực mạch phổi PVR.

\section{Yếu tố nguy cơ liên quan tăng áp động mạch phổi}

Bảng 6. Yếu tố nguy cơ liên quan tăng áp động mạch phổi (Logistic đa biến)

\begin{tabular}{lccc}
\hline \multirow{2}{*}{ Tên biến độc lập } & \multicolumn{3}{c}{ Biến phụ thuộc nguy cơ tăng áp động mạch phổi } \\
\cline { 2 - 4 } & OR & p & Khoảng tin cậy $\mathbf{~ C l ~}$ \\
\hline NYHA & 1,05 & 0,02 & $1,163-7,002$ \\
\hline Khoảng cách đi bộ 6 phút & 0,003 & 0,31 & $0,992-1,003$ \\
\hline NT - proBNP & 0,001 & 0,01 & $1,00-1,002$ \\
\hline
\end{tabular}

Mức độ khó thở NYHA và NT - proBNP là yếu tố độc lập liên quan đến tăng áp động mạch phổi.

\section{BÀN LUẬN}

Nghiên cứu của chúng tôi nghiên cứu trên hai bệnh là lupus ban đỏ hệ thống (137 bệnh nhân) và xơ cứng bì (62 bệnh nhân), chia hai đối tượng thành 2 nhóm có tăng áp động mạch phổi và không tăng áp động mạch phổi. Đặc điểm tuổi, giới và thời gian mắc bệnh của 2 nhóm có và không có tăng áp động mạch phổi trên cả hai bệnh trên là như nhau. Khi phân tích sự biến đổi về chức năng thất phải trên hai bệnh lí lupus ban đỏ hệ thống, chúng tôi thấy không có sự khác biệt giữa hai nhóm có tăng áp động mạch phổi và không có tăng áp động mạch phổi. Trong khi đó, ở bệnh lí xơ cứng bì, có sự khác biệt rõ rệt về chỉ số thất phải (FAC) và kháng lực mạch phổi giữa nhóm có và không có tăng áp động mạch phổi. Về lâm sàng và cận lâm sàng, chúng tôi cũng nhận thấy cả bệnh lí lupus ban đỏ hệ thống và xơ cứng bì đều thấy có sự khác biệt rõ rệt về khoảng cách đi bộ 6 phút, nồng độ NT - pro BNP mức độ 
khó thở NYHA giữa nhóm không tăng áp động mạch phổi và có tăng áp động mạch phổi. Phân tích hồi quy đa biến cho kết quả có hai yếu tố nguy cơ độc lập liên quan đến tăng áp động mạch phổi ở bệnh nhân lupus ban đỏ hệ thống và xơ cứng bì là NTproBNP và mức độ khó thở NYHA, trong khi test đi bộ 6 phút thì không. Trong các tổn thương phổi của bệnh tự miễn có tổn thương phổi kẽ cũng gây ra sự thay đổi khoảng cách đi bộ 6 phút, đặc biệt ở bệnh nhân xơ cứng bì. ${ }^{8}$

Nồng độ NT - proBNP ở nhóm tăng áp động mạch phổi cao hơn hẳn so với nhóm không tăng áp động mạch phổi, 384,91pg/mL so với $128,24 \mathrm{pg} / \mathrm{mL}$ ở bệnh lí lupus ban đỏ hệ thống, và 288,82 so với $53,85 \mathrm{pg} / \mathrm{mL}$ ở bệnh lí xơ cứng bì ( $p<0,05$ ở cả hai trường hợp). NT - proBNP là dấu ấn sinh học phản ánh đáp ứng của cơ tim với áp lực và quá tải thể tích, ${ }^{5}$ biến đổi song song với thay đổi trong cấu trúc và chức năng thất phải. ${ }^{6}$ Khi áp lực động mạch phổi tăng lên, dẫn đến sự quá tải về áp lực và sự biến đổi cấu trúc, chức năng thất phải, điều này làm cho sự tăng phóng thích NT - proBNP vào trong máu. Trong nghiên cứu của chúng tôi cho thấy, giá trị nồng độ NT - proBNP có mối tương quan thuận với chỉ số áp lực động mạch phổi tâm thu ở cả hai bệnh lí lupus ban đỏ hệ thống và xơ cứng bì, mặc dù mối tương quan này không chặt, chỉ số tương quan lần lượt là 0,28 và $0,49(p<0,05)$. Kết quả này tương tự nghiên cứu của $Y$ Allanore và cộng sự năm $2003,{ }^{9}$ kết quả nghiên cứu cho thấy giá trị NT - proBNP tương quan với số đo áp lực động mạch phổi tâm thu $(\rho=0,44, p=0,006)$. Tác giả cũng khẳng định nồng độ NT - proBNP có thể sử dụng trong chẩn đoán sớm tăng áp động mạch phổi ở bệnh nhân xơ cứng bì khi chưa có dấu hiệu suy tim. Và trong một nghiên cứu khác trên bệnh nhân lupus ban đỏ hệ thống, tác giả Leila Ghofraniha cũng thấy rằng nồng độ NT proBNP ở nhóm có tăng áp động mạch phổi là 347 pg/ml cao hơn hẳn so với nhóm không tăng áp động mạch phổi là 72.16 pg/ml $(p<0,05) .{ }^{10}$

Ngoài ra, để đánh giá chức năng thất phải trong tăng áp phổi còn có thể sử dụng những biện pháp gắng sức, trong đó test đi bộ 6 phút (6MWD) là test thường được sử dụng nhằm đo lường khả năng đáp ứng của chức năng tim, phổi với gắng sức. Theo kết quả nghiên cứu của chúng tôi, ở cả hai bệnh lí lupus ban đỏ hệ thống và xơ cứng bì có sự khác biệt giữa khoảng cách đi bộ 6 phút giữa nhóm có tăng áp động mạch phổi và không tăng áp động mạch phổi $(372,42$ so với 467,40 và 327,50 so với $375,00, p<0,05)$. Tuy nhiên, khi đánh giá mối tương quan, thì khoảng cách đi bộ 6 phút có tương quan với áp lực động mạch phổi tâm thu ở bệnh lí lupus ban đỏ hệ thống $(r=-0,39, p=$ 0,00 ), nhưng không có mối tương quan ở bệnh lí xơ cứng bì. Trong một nghiên cứu năm 2006, Sushmita $P$ và cộng sự đã nghiên cứu mối liên quan giữa khoảng cách đi bộ 6 phút với nghiệm pháp tim phổi gắng sức ở bệnh nhân bệnh tự miễn có tăng áp động mạch phổi. ${ }^{11}$ Tác giả đưa ra kết luận khoảng cách đi bộ 6 phút có mối tương quan với mức độ nặng của tăng áp động mạch phổi. Còn trong một nghiên cứu khác của Harrison W.F và cộng sự năm 2015, ${ }^{12}$ tác giả đưa ra kết luận, khoảng cách đi bộ trung bình là $360 \pm 129 \mathrm{~m}$. So với đánh giá huyết động thì khoảng cách đi bộ 6 phút tương quan nghịch với áp lực nhĩ phải $(r=-0,198, p<0,001)$ và áp lực động mạch phổi bít ( $r=-0,077, p<0,001)$. Không có mối tương quan giữa sức cản mạch phổi hoặc áp lực động mạch phổi trung bình với khoảng cách đi bộ 6 phút. Tuy nhiên, trong kết quả nghiên cứu của chúng tôi thì thấy rằng không có mối tương quan giữa khoảng cách đi bộ 6 phút với áp lực nhĩ phải, kháng lực mạch phổi trên cả hai bệnh lí xơ cứng bì và lupus ban đỏ hệ thống. Như vậy, khoảng cách đi bộ 6 phút có ý nghĩa đánh giá mức độ nặng của tăng áp động mạch phổi trên bệnh lí lupus ban đỏ hệ thống hơn là bệnh nhân xơ cứng bì.

Cũng theo kết quả nghiên cứu, mức độ khó 
thở theo NYHA ở nhóm tăng áp động mạch phổi cao hơn hẳn nhóm không tăng áp động mạch phổi, trên bệnh nhân lupus ban đỏ hệ thống là 1,88 so với $1,28(p=0,00)$, trên bệnh nhân xơ cứng bì là 2,00 so với 1,62 ( $p=0,01)$. Mức độ khó thở NYHA cũng có mối tương quan với các chỉ số chức năng thất phải trên bệnh nhân lupus ban đỏ hệ thống có mối tương quan nghịch với giá trị TAPSE và FAC, còn trên bệnh nhân xơ cứng bì mức độ khó thở NYHA tương quan thuận với kháng lực mạch phổi. Điều này phù hợp với $X$. Shang và cộng sự, nghiên cứu cho thấy phân độ NYHA có mối tương quan đến chức năng thất phải, cả trên siêu âm tim và cả MRI tim. ${ }^{7}$

Trong khuyến cáo mới nhất của ESC/ERS về tăng áp động mạch phổi năm 2015 có đề cập đến vai trò của các xét nghiệm chất chỉ thị sinh học trong đánh giá nguy cơ và tiên lượng nặng của tăng áp động mạch phổi. ${ }^{13}$ Nồng độ $\mathrm{N}$ - terminal pro - brain natriuretic peptide (NT - proBNP) cũng có tương quan đáng kể với huyết động, ngay cả khi siêu âm tim bình thường. Nồng độ NT - proBNP tăng trên 3 lần giới hạn trên của mức bình thường có thể nghĩ đến tăng áp động mạch phổi. Ngoài ra khoảng cách đi bộ 6 phút, NYHA có vai trò trong khả năng dung nạp gắng sức của cơ thể khi thay đổi chức năng thất phải. Từ kết quả của nghiên cứu, chúng tôi nhận thấy vai trò phát hiện sớm nguy cơ tăng áp động mạch phổi có thể dựa trên sự tăng nồng độ NT - proBNP và tăng mức độ nặng khó thở NYHA, từ đó chỉ định cho bệnh nhân siêu âm đánh giá áp lưc động mạch phổi và chức năng thất phải, giúp chẩn đoán sớm và điều trị kịp thời cho bệnh nhân tăng áp động mạch phổi.

\section{KÉT LUÂN}

Nồng độ NT - proBNP và khoảng cách đi bộ 6 phút, NYHA có mối tương quan với chỉ số áp lực động mạch phổi tâm thu. Trong đó, mức độ khó thở NYHA và nồng độ NT - proBNP là những yếu tố nguy cơ độc lập liên quan đến tăng áp động mạch phổi. Khi nồng độ NT proBNP tăng cao và giảm khả năng gắng sức tăng lên theo thang điểm gắng sức NYHA, chúng ta thấy rằng nguy cơ tăng áp động mạch phổi tăng lên, là dấu hiệu cần lưu ý để chẩn đoán và điều trị sớm tăng áp động mạch phổi. Nghiên cứu trên số lượng bệnh nhân còn hạn chế, ngoài ra một số bệnh nhân vẫn dùng thuốc điều trị tăng áp động mạch phổi hoặc thuốc ảnh hưởng đến áp lực mạch phổi khi đến làm siêu âm và xét nghiệm nên có thể có sai số khi phân tích kết quả.

\section{TÀI LIẸU THAM KHẢO}

1. Proudman S, Stevens W, Sahhar J, Celermajer D. Pulmonary arterial hypertension in systemic sclerosis: the need for early detection and treatment. Internal medicine journal. 2007;37 (7):485 - 494.

2. Kasitanon N, Magder LS, Petri M. Predictors of survival in systemic lupus erythematosus. Medicine. 2006;85 (3):147 156.

3. Chen H - A, Hsu T - C, Yang S - C, et al. Incidence and survival impact of pulmonary arterial hypertension among patients with systemic lupus erythematosus: a nationwide cohort study. Arthritis Research \& Therapy. 2019;21 (1):82.

4. Demir R, Küçükoğlu MS. Six - minute walk test in pulmonary arterial hypertension. Anatolian journal of cardiology. 2015;15 (3):249.

5. Williams $\mathrm{MH}$, Handler CE, Akram R, et al. Role of $\mathrm{N}$ - terminal brain natriuretic peptide (N - TproBNP) in scleroderma - associated pulmonary arterial hypertension. European heart journal. 2006;27 (12):1485 - 1494.

6. Gan T, McCann GP, Marcus JT, et al. NT - proBNP reflects right ventricular structure and function in pulmonary hypertension. European Respiratory Journal. 2006.

7. Shang X, Xiao S, Dong N, et al. Assessing 
right ventricular function in pulmonary hypertension patients and the correlation with the New York Heart Association (NYHA) classification. Oncotarget. 2017;8 (52):90421.

8. Rosa R, Santos AS, Coelho R, et al. The relation of six - minute walk test and lung function in interstitial lung disease. Eur Respiratory Soc; 2013.

9. Allanore $\mathrm{Y}$, Borderie D, Meune $\mathrm{C}$, et al. $\mathrm{N}$ - terminal pro - brain natriuretic peptide as a diagnostic marker of early pulmonary artery hypertension in patients with systemic sclerosis and effects of calcium - channel blockers. Arthritis \& Rheumatism: Official Journal of the American College of Rheumatology. 2003;48 (12):3503 - 3508.

10. Ghofraniha L, Mirfeizi Z, Khabbaz FS, Vakilian F, Eslami S. Correlation of echocardiographic findings of pulmonary hypertension with six - minute walk test and plasma pro b - type natriuretic peptide level in systemic lupus erythematous. Electronic physician. 2017;9 (8):5122.
11. Pamidi S, Mehta S. Relationship between the six - minute walk test and cardiopulmonary exercise test parameters in connective tissue disease - associated pulmonary arterial hypertension. Chest. 2006;130 (4):120S.

12. Farber HW, Miller DP, McGoon MD, Frost AE, Benton WW, Benza RL. Predicting outcomes in pulmonary arterial hypertension based on the 6 - minute walk distance. The Journal of Heart and Lung Transplantation. 2015;34 (3):362 - 368.

13. Galiè N, Humbert M, Vachiery J - L, et al. 2015 ESC/ERS Guidelines for the diagnosis and treatment of pulmonary hypertension: the Joint Task Force for the Diagnosis and Treatment of Pulmonary Hypertension of the European Society of Cardiology (ESC) and the European Respiratory Society (ERS): endorsed by: Association for European Paediatric and Congenital Cardiology (AEPC), International Society for Heart and Lung Transplantation (ISHLT). European heart journal. 2015;37 (1):67 - 119.

\section{Summary \\ RISK FACTORS OF PULMONARY ARTERIAL HYPERTENSION IN PATIENTS WITH SCLERODERMA AND SYSTEMIC LUPUS ERYTHEMATOSUS}

Echocardiography, the 6 - minute walking test, NT proBNP and NYHA are valuable for screening and assessing severe scleroderma, systemic lupus erythematosus. This study was conducted to evaluate the rick factors related pulmonary arterial hypertension among scleroderma, systemic lupus erythematosus. A cross - sectional descriptive study on 137 patients with SLE and 62 patients with SSc, including 138 patients without PAH and 61 patients with PAH ( > 36mmHg), was conducted at the Center of Allergy - Clinical Immunology. Bach Mai Hospital, National Institute of Dermatology, from August 2016 to August 2020. Results showed that level NT proBNP, and NYHA score in patients with PAH were higher, while the 6 minutes walking test were shorter. NT proBNP and NYHA score were the risk factors related to PAH.

Keywords: pulmonary arterial hypertension, scleroderma, systemic lupus erythematosus, NT - proBNP, NYHA. 